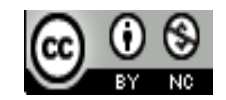

Jurnal Pendidikan Bahasa dan Sastra Indonesia is licensed under

A Creative Commons Attribution-Non Commercial 4.0 International License

\title{
Pemahaman Guru Sekolah Dasar Kabupaten Melawi Kalimatan Barat dalam Menulis Kalimat Bahasa Indonesia (Studi Kasus Peserta PPG Daerah Khusus)
}

\author{
Apri Damai Sagita Krissandi ${ }^{1)}$, Kelik Agung Cahya Setiawan ${ }^{2)}$ \\ 1) Program Studi PGSD Universitas Sanata Dharma Yogyakarta \\ E-mail:apridamai@gmail.com \\ ${ }^{2)}$ Program Studi Pendidikan Bahasa dan Sastra Indonesia Universitas Negeri Yogyakarta \\ E-mail: keliksky49@gmail.com
}

\begin{abstract}
Abstrak. Tujuan dari penelitian ini adalah untuk mendeskripsikan pemahaman guru sekolah dasar Kabupaten Melawi Kalimantan Barat dalam menulis kalimat bahasa Indonesia sesuai dengan strukutur dan pola kalimat. Jenis penelitian adalah kualitiatif deskriptif. Data berupa kontruksi kalimat bahasa Indonesia yang didapat dari hasil kuisioner yang diberikan kepada guru-guru sekolah dasar Kabupaten Melawi yang mengikuti Pendidikan Profesi Guru (PPG) daerah khusus yang berjumlah tiga puluh satu peserta. Instrumen penelitan adalah berupa soal. Keabsahan data yang dilakukan dengan menggunakan trianggulasi. Hasil penelitan menunjukan bahwa pemahaman menulis guru Kabupaten Melawi Kalimantan Barat termasuk dalam kriteria "cukup baik". Hal tersebut dapat dilihat dari persentase jawaban yanng benar sebanyak 64\% sedangkan yang tidak sesuai dengan instruksi adalah 36\%. Kesalahan yang dilakukan para guru meliputi: (1) Ketidakpahaman Konsep Subjek; (2) Kesalahan Pemahaman Objek; (3) Kesalahan Penempatan Keterangan; (4) Kesalahan Fungsi Pelengkap.
\end{abstract}

Kata Kunci: kemampuan menulis; pendidikan profesi guru; kalimat Bahasa Indonesia, guru SD Kabupaten Melawi

\section{PENDAHULUAN}

Keberhasilan dalam pembelajaran sangat ditentukan oleh peranan guru dalam pelaksanaan pembelajaran. Tidak dapat dipungkiri peran guru dalam pembelajaran merupakan faktor utama serta ujung tombak dalam upaya meningkatkan mutu pendidikan. Namun akhir-akhir ini guru menjadi bahan sorotan terkait dengan pelaksanaan pembelajaraan. Kurangnya profesionalitas guru menjadi bahan bahan kajian utama yang sering diangkat di berbagai seminar atau penelitian yang dilakukan. Seperti halnya pada penelitan yang dilakukan United Nations Education, Scientific and Cultural Organization (UNESCO) yang di kutip dari Cuttence (2018:2) menyatakan bahwa peringkat kualitas para guru, berada pada level 14 dari 14 negara berkembang. Penelitan tersebut menunjukan bahwa profesionalitas guru dalam pelaksanaan pembelajaran masih rendah. Hal tersebut menjadi salah satu alasam pemerintah memunculkan suatu kebijakan mengenai suatu program dimana program tersebut dapat menambah kualitas guru yang ada di Indonesia yaitu Pendidikan Profesi Guru (PPG). Program Profesi Guru merupakan suatu program pendidikan yang dilaksanakan dalam mempersiapkan lulusan S1/D IV kependidikan maupun non kependidikan yang mempunyai minat menjadi guru untuk menguasai kompetensi guru secara keseluruhan sesuai dengan strandar nasional kependidikan. Kabupaten Melawi merupakan kabupaten baru di Kalimantan Barat. Dasar hukum pembentukan Kabupaten Melawi ini diatur dalam Undang-Undang Republik Indonesia Nomor 34 Tahun 2003. Sebagai kabupaten yang belum lama terbentuk, Kabupaten Melawi termasuk daerah 3T (Terdepan, Terluar, Tertinggal). Untuk meningkatkan kualitas sumber daya manusia khususnya guru, pemerintah memberikan kesempatan kepada guru lulusan S1/DIV, untuk mengikuti Pendidikan Profesi Guru.

Kemampuan menulis merupakan suatu kemampuan dalam mengungkapkan sesuatu dalam pikiran dalam sebuah tulisan (Brown, 2007:81). Lebih lanjut Iskandarwassid dan Sunendar (2013:248) menyatakan bahwa menulis merupakan suatu bentuk manifestasi pemahaman serta keterampilan akan bahasa yang dikuasai setelah kemampuan menyimak, berbicara, serta membaca. Alred, dkk (2009:xv) "Successful writing on the job is not the product of inspiration, nor is itmerely the spoken word converted to print; it is the result of knowing how to structure information using both text and design to achieve an intended purpose for a clearly defined audience." Dari pendapat tersebut makan dapat dikatakan bahwa menulis yang bagus bukan hanya dari hasil dari inspirasi dan kata yang dirubah menjadi sebuah tulisan namun juga mengetahui struktur kalimat dan bentuk-bentuk kalimat. Levison (1983:15) berpendapat 
bahwa penggunaan bahasa yang merupakan alat komunikasi dalam pragmatik mempunyai kaidah yang harus dipatuhi oleh penutur dan mitra tutur. Keraf (1984:156) berpendapat bahwa bagian yang membahas mengenai pembentukan kalimat dan struktur kalimat adalah sintaksis. Adapun salah satu aspek dalam sintaksis adalah struktur dal pola kalimat.

Seperti yang dijelaskan sebelumnya, guru merupakan faktor utama serta ujung tombak dalam upaya meningkatkan mutu pendidikan khususnya dalam pelaksanaan pemebelajaran memerlukan suatu pemahaman dalam menulis kalimat bahasa Indonesia sesuai dengan strukutur dan pola kalimat. Pemahaman akan struktur dan pola kalimat tersebut menjadi hal utama untuk guru khususnya guru sekolah dasar. Pendidikan dasar menurut UU 20 tahun 2003 merupakan jenjang pendidikan yang diselenggarakan untuk mengembangkan sikap, kemampuan, pengetahuan, dan keterampilan dasar yang diperlukan dalam rangka mempersiapkan kehidupan serta mempersiapkan perserta didik untuk mengikuti jenjang pendidikan selanjutnya. Salah satu bentuk untuk mengembangkan keterampilan dasar adalah memberikan keterampilan dasar menulis. Hal tersebut bertujuan untuk memberikan pembiasaan kepada peserta didik untuk menulis kalimat bahasa Indonesia sesuai dengan struktur dan pola kalimat. Agar dapat memberikan pembiasaan menulis kalimat bahasa Indonesia kepada peserta didik, maka seorang guru wajib untuk memahami struktur dan pola kalimat bahasa Indonesia sesuai dengan tata bahasa. Berdasarkan permasalahan tersebut, penelitian bertujuan untuk mendeskripsikan pemahaman guru sekolah dasar Kabupaten Melawi Kalimantan Barat dalam menulis kalimat bahasa Indonesia sesuai dengan strukutur dan pola kalimat.

\section{METODE}

Penelitian merupakan penelitian kualitatif deskriptif. Tujuan dari penelitan ini adalah mendeskripsikan pemahaman guru sekolah dasar Kabupaten Melawi Kalimantan Barat dalam menulis kalimat bahasa Indonesia sesuai dengan strukutur dan pola kalimat. Penelitan dilaksanakan pada guru yang mengikuti Pendidikan Profesi Guru (PPG) pada tahun 2018 daerah khusus yang berasal dari Kabupaten Melawi. Objek pada penelitian ini adalah pemahaman pemahaman menulis guru sekolah dasar dalam struktur dan pola bahasas Indonesia. Subjek dalam penelitian ini adalah guru yang berasal dari Kabupaten Melawi yang berjumlah 31 orang. Berikut sebaran asal sekolah dasar responden.

Tabel 1. Sebaran Asal Sekolah Responden

\begin{tabular}{|l|c|}
\hline Tempat Mengajar & Jumlah \\
\hline SD N Sungai Pinang & 1 \\
\hline SD Nusa Onap & 1 \\
\hline SD 12 Kepala Gading & 2 \\
\hline SD 10 Nanga Kempangai & 1 \\
\hline SD 16 Suka Damai & 1 \\
\hline SD N 24 Lanjau & 1 \\
\hline
\end{tabular}

\begin{tabular}{|l|l|}
\hline SD N 5 Nanga Nuak & 1 \\
\hline SD N 09 Kedupai & 1 \\
\hline SD N 12 Lahai & 2 \\
\hline SD N 14 Kelakik & 1 \\
\hline SD 4 Nyatang & 1 \\
\hline SD N 16 Semadin & 1 \\
\hline SD N 21 Mentawak & 1 \\
\hline SD N 23 Senibung Laut & 1 \\
\hline SD N 20 Tanjung Keramat & 1 \\
\hline SD Negeri Jabai & 1 \\
\hline SD N 10 Manding & 1 \\
\hline SD N 24 Lumut & 1 \\
\hline SD N 7 Sungai Bakah & 1 \\
\hline SD N 7 Nangapak & 1 \\
\hline SD N 11 Bata & 1 \\
\hline Tidak menyebutkan sekolah asal & 8 \\
\hline Jumlah & 31 \\
\hline
\end{tabular}

Sumber: Analisis Data, 2018

Dilihat dari tabel 1, sebaran asal sekolah subjek penelitian meliputi berbagai wilayah yang terletah di Kabupaten Melawi Kalimantan Barat. Meskipun terdapat beberapa subjek yang tidak menyebutkan sekolah asal, namun jika dilihat dari sebaran yang digunakan sebagai sampel, dapat digunakan mewakili seluruh populasi sekolah yang terdapat di Kabupaten Melawi. Teknik pengumpulan data yang dilakukan pada penelitian ini adalah dengan menggunakan tes tertulis yang dikenakan terhadap seluruh responden dengan instrumen soal uraian dengan instruksi membuat kalimat dengan menggunakan sturktur dan pola kalimat S-P, , S-P-O, S-P-O-K, K-S-P-O. Keabsahan data yang digunakan dalam penelitian ini adalah dengan menggunakan kriteria derajat kepercayaan. Untuk mendukung dan menjaga kredibulitas peneliti menggunakan validasi truanggulasi. Dalam menganalisis data peneliti menggunakan tiga jalur kegiatan yang dilakukan secara stimulan yaitu (reduksi, penyajian data, penarikan kesimpulan). (a) reduksi data yaitu proses pemilihan, pemusatan, penyederhanaan, pengabstrakan, transformasi data dari catatan penulis dari lapangan. (b) penyajian data, yaitu menyajikan data yang sudah disusun untuk selanjutnya digunakan untuk menarik kesimpulan. (c) pernarikan kesimpulan, penarikan kesimpulan dilakukan denngan mencari arti dan mengurutkan data serta pola dari aawal pengumpulan data.

\section{PEMBAHASAN}

Penelitian ini memfokuskan pada pemahaman guru dalam menulis struktur dan pola kalimat bahasa Indonesia. Untuk mengetahui pemahaman guru tersebut penelitian memberikan soal dengan intruksi membuat empat kalimat dengan struktur dan pola kalimat (a.) S-P, (b) S-P-O, (c) S$\mathrm{P}-\mathrm{O}-\mathrm{K}$, (d) K-S-P-O. Berdasarkan instrumen soal tersebut, berikut hasil dari jawaban responden: 
Gambar 1. Persentase Hasil Jawaban Responden

- Persentase jawaban yang tidak sesuai dengan instruksi - Persentase Jawaban yang sesuai dengan instruksi

Gambar 1 merupakan menjelaskan mengenai persentase keseluruhan jawaban yang dibuat guru dalam menyelesaikan instrumen berupa soal, baik yang sesuai dengan instruksi dan yang tidak sesuai instruksi. Dari hasil jawaban instrumen soal tersebut didapati bahwa persentase jawaban yanng benar sebanyak $64 \%$ sedangkan yang tidak sesuai dengan instruksi adalah 36\%. Dari hasil persentase tersebut dapat diidentifikasikan bahwa pemahaman guru dalam menulis kalimat dengan struktur dan pola kalimat dapat dikatakan "cukup baik", namun masih ada beberapa guru yang belum begitu paham dalam menulis kalimat bahasa Indonesia. Berikut beberapa kesalahan yang dibuat guru dalam membuat kalimat dengan struktur dan pola kalimat bahasa Indonesia:

\section{KETIDAKPAHAMAN KONSEP SUBJEK}

Subjek adalah suatu hal yang wajib dalam setiap kaklimat dikarenakan subjek merupakan unsur yang paling pokok yang secara umum berupa kata benda yang mempunyai fungsi mewakili aktivitas dan perbuatan tertentu dalam kalimat. Berikut kesalahan yang dibuat oleh responden dalam membentuk kalimat:

Tabel 3. Ketidakpahaman Subjek dalam Kalimat

\begin{tabular}{c}
\hline Instruksi yang diberikan \\
K-S-P-O \\
Di dapur sedang memasak sayur \\
Sumber: Analisis Data, 2018
\end{tabular}

Kalimat di atas menunjukan kesalahan responden terhadap fungsi subjek. Instruksi dalam instrumen soal adalah membuat kalimat K-S-P-O namun responden tidak memberi subjek dalam kalimat. Hal tersebut menunjukan bahwa responden belum paham terhadap konsep subjek.

\section{KESALAHAN PEMAHAMAN OBJEK}

Keberadaan objek pada suatu kalimat bahasa Indonesia adalah suatu bagian kalimat yang dipengaruhi oleh predikat yang berupa verba transitif. Jika suatu kalimat aktif dijadikan kalimat pasif, maka objek dapat menjadi subjek. Objek biasanya berupa frasa nomina, nmaun juga dapat berupa klausa. Berikut kesalahan yang dibuat oleh responden terkait dengan fungsi objek.
Tabel 2. Kesalahan Pemahaman Objek Instruksi yang diberikan

\begin{tabular}{|c|c|c|c|}
\hline S-P & S-P-O & S-P-O-K & K-S-P-O \\
\hline $\begin{array}{l}\text { Indah } \\
\text { pergi } \\
\text { kepasar }\end{array}$ & $\begin{array}{l}\text { Ayah pergi ke } \\
\text { ladang }\end{array}$ & $\begin{array}{l}\text { Ibu pergi } \\
\text { kepasar sayur }\end{array}$ & $\begin{array}{l}\text { Jagung di panen } \\
\text { paman dari } \\
\text { kebun }\end{array}$ \\
\hline $\begin{array}{l}\text { Ibu ke } \\
\text { pasar }\end{array}$ & $\begin{array}{l}\text { Ibu pergi } \\
\text { kepasar }\end{array}$ & $\begin{array}{l}\text { Ibu pergi } \\
\text { kepasar tadi } \\
\text { pagi }\end{array}$ & $\begin{array}{l}\text { Tadi pagi Ibu } \\
\text { pergi ke Pasar }\end{array}$ \\
\hline \multirow[t]{11}{*}{$\begin{array}{l}\text { Rina } \\
\text { pergi ke } \\
\text { pasar }\end{array}$} & $\begin{array}{l}\text { Saya pergi ke } \\
\text { pasar }\end{array}$ & $\begin{array}{l}\text { Indah pergi } \\
\text { kepasar malam } \\
\text { tadi malam }\end{array}$ & $\begin{array}{l}\text { tadi malam } \\
\text { Indah pergi ke } \\
\text { pasar malam }\end{array}$ \\
\hline & Indah pergi & Rina pergi & Di Pasar \\
\hline & kepasar & kepasar & sayuran Ibu \\
\hline & malam & $\begin{array}{l}\text { Malioboro tadi } \\
\text { malam }\end{array}$ & belanja \\
\hline & $\begin{array}{l}\text { Ibu membeli } \\
\text { sayur kepasar }\end{array}$ & $\begin{array}{l}\text { Kakak } \\
\text { menangis di } \\
\text { kamar saya }\end{array}$ & $\begin{array}{l}\text { Tadi pagi Rina } \\
\text { pergi kepasar } \\
\text { malioboro }\end{array}$ \\
\hline & $\begin{array}{l}\text { Rina pergi } \\
\text { kepasar } \\
\text { malioboro }\end{array}$ & $\begin{array}{l}\text { Randi belajar } \\
\text { membaca di } \\
\text { Sekolah }\end{array}$ & $\begin{array}{l}\text { Ke pulau Jawa } \\
\text { adik pergi } \\
\text { merantau }\end{array}$ \\
\hline & $\begin{array}{l}\text { Saya pergi ke } \\
\text { sekolah }\end{array}$ & $\begin{array}{l}\text { saya datang di } \\
\text { Yogyakarta } \\
\text { pada tanggal } 2 \\
\text { Agustus } 2018\end{array}$ & $\begin{array}{l}\text { Setiap hari kami } \\
\text { belajar di } \\
\text { kampus }\end{array}$ \\
\hline & $\begin{array}{l}\text { Ibu pergi } \\
\text { kepasar }\end{array}$ & $\begin{array}{l}\text { Andi pergi ke } \\
\text { sekolah } \\
\text { menggunakan } \\
\text { sepeda }\end{array}$ & $\begin{array}{l}\text { Ke sekolah } \\
\text { Adik pergi } \\
\text { belajar }\end{array}$ \\
\hline & $\begin{array}{l}\text { Saya pergi Ke } \\
\text { pasar }\end{array}$ & $\begin{array}{l}\text { Adik pergi } \\
\text { merantau ke } \\
\text { pulau Jawa }\end{array}$ & \\
\hline & $\begin{array}{l}\text { Kakak } \\
\text { menangis di } \\
\text { Kamar }\end{array}$ & $\begin{array}{l}\text { saya pergi } \\
\text { kepasar untuk } \\
\text { membeli ikan }\end{array}$ & $\begin{array}{l}\text { Karena ngantuk } \\
\text { Ani tidur }\end{array}$ \\
\hline & & $\begin{array}{l}\text { Andi pergi ke } \\
\text { sekolah } \\
\text { menggunakan } \\
\text { sepeda } \\
\text { televisi dirumah } \\
\text { sedang rusak } \\
\quad \text { Sumber. }\end{array}$ & $\begin{array}{l}\text { Di sekolah } \\
\text { Randi belajar } \\
\text { membaca }\end{array}$ \\
\hline
\end{tabular}

Tabel 2 menunjukan kesalahan terkait ketidakpahaman responden terhadap objek. Dari kesalahan kalimat di atas, menunjukan bahwa responden masih belum dapat membedakan antara objek dan keterangan dimana keterangan dalam kalimat yang dibuat dianggap sebagai objek dalam kalimat.

\section{KESALAHAN PENEMPATAN KETERANGAN}

Keterangan merupakan penjelas dalam struktur dan pola kalimat bahasa Indonesia. Keterangan dapat berupa keterangan tempat, waktu, cara dan lain-lain. Adapun beberapa kesalahan yang dibuat oleh responden adalah ketidakpahaman responden terkait dengan penempatan keterangan. Berikut adalah kesalahan kalimat yang dibuat responden terkait dengan penempatan keterangan. 
Tabel 4. Kesalahan Penempatan Keterangan Instruksi yang diberikan S-P-O-K

Wati pergi ke pasar membeli baju Saya pergi ke pasar membeli Tomat

Sumber: Analisis Data, 2018

Tabel 3 menunjukan kesalahan yang dibuat responden terkait dengan penempatan keterangan dalam pola kalimat. Hal tersebut ditunjukan dari ketidaksesuaian instruksi yang diberikan dengan jawaban responden. Instruksi yang diberikan adalah membuat kalimat dengan struktur dan pola kalimat S-P-O-K, namun dari kalimat pada tebel menunjukan bahwa responden membuat kalimat manjemuk setara dengan pola kalimat S-P-K-(S)-P-O. Jadi dapat disimpulkan bahwa ada beberapa guru yang belum memahami konsep penempatan keterangan.

Kesalahan lain yang terlihar dari hasil jawaban responden terkait dengan keterangan adalah dengan menampahkan keterangan tanpa tanda instruksi hal tersebut ditunjukan dari kalimat berikut:

Tabel 5. Kesalahan Penambahan Keterangan Instruksi yang diberikan

$$
\mathrm{K}-\mathrm{S}-\mathrm{P}-\mathrm{O}
$$

dengan lahap saya makan apel yang manis

Sumber: Analisis Data, 2018

Tabel di atas menunjukan kesalahan yang dibuat responden yang tidak sesuai instruksi terkait penambahan keterangan tanpa di minta. Hal tersebut ditunjukan dari instruksi kalimat dengan pola K-S-P-O, namun responden menjawab dengan K-S-P-O-K.

\section{KESALAHAN FUNGSI PELENGKAP}

Pelengkap merupakan kalimat yang hampir sama dengan objek, tapi yang membedakan adalah jika kalimat diubah menjadi kalimat pasif pelengkap tidak dapat diubah menjadi subjek, sedangkan objek dapat diubah menjadi subjek. Secara umum pelengkap berposisi setelah predikat atau setelah objek dan biasanya predikat diawali dengan awalan ber-. Banyak orang sulit membedakan fungsi pelengkap dan objek. Ketidakpahaman pelengkap ini juga dialami oleh guru SD di Kabupaten Melawi. Berikut merupakan kesalahan fungsi pelengkap.

Tabel 6. Kesalahan Fungsi Pelengkap

\begin{tabular}{ccc}
\hline \multicolumn{3}{c}{ Instruksi yang diberikan } \\
\hline S-P-O & \multicolumn{1}{c}{ S-P-O-K } & K-S-P-O \\
\hline $\begin{array}{l}\text { Adik sedang } \\
\text { bermain }\end{array}$ & $\begin{array}{l}\text { Budi bermain } \\
\text { bola di Lapangan }\end{array}$ & $\begin{array}{l}\text { Di taman, Edo } \\
\text { bermain bola }\end{array}$ \\
\end{tabular}

Gino bermain

bola

Sumber: Analisis Data, 2018
Tabel di atas menunjukan kesalahan kalimat yang dibuat oleh responden terkait dengan fungsi pelengkap. Keempat kalimat yang dibuat oleh guru tersebut menunjukan kalimat intransitif. Adapun salah satu ciri kalimat intransitif adalah predikat yang mempunyai awalan ber-dan berpola S-P-Pel. Dari keempat kalimat tersebut dapat diidentifikasi bahwa responden kurang memahami akan konsep pelengkap. Dari hasil wawancara didapati bahwa kesalahan yang dibuat adalah tidak dapat membedakan antara fungsi pelengkap dan fungsi objek.

\section{IV.SIMPULAN}

Pemahaman menulis guru Sekolah Dasar di Kabupaten Melawi tergolong "cukup baik". Hal tersebut dapat dilihat dari kesesuaian antara intruksi dalam instrumen yang diberikan kepada responden. Hasil tersebut menunjukan bahwa persentase jawaban yanng benar sebanyak $64 \%$ sedangkan yang tidak sesuai dengan instruksi adalah $36 \%$. Instruksi yang ada dalam instrumen adalah responden diminta untuk membuat kalimat dengan menggunakan struktur dan pola kalimat S-P, S-P-O, S-P-O-K, K-S-P-O. Beberapa kesalahan yang dibuat guru meliputi (1) Ketidakpahaman Konsep Subjek; (2) Kesalahan Pemahaman Objek; (3) Kesalahan Penempatan Keterangan; (4) Keslahan Fungsi Pelengkap.

\section{DAFTAR PUSTAKA}

Browne, A. (2007). Teaching and learning communication, language and literacy. Landon: Paul Chapman Publishing.

Cuttence, P. (2001). School innovation, pathway to the knowledge society. Departement of Education Australia.

https://web.archive.org/web/20050224091736/http://w ww.dest.gov.au/. Diakses 25 Mei 2018

Depdiknas. (2003). Undang-Undang Republik Indonesia Nomor 20 Tahun 2003 tentang Sistem Pendidikan Nasional. Jakarta: Depdiknas.

Gerald J., Charles T.B, Walter E.O. (2009). Handbook of technical writing. Boston: Bedford/St. Martin's.

Iskandarwassid, \& Sunendar. (2013). Strategi pembelajaran bahasa. Bandung: PT. Remaja Rosdakarya.

Keraf, G. (1984). Diksi dan Gaya Bahasa. Jakarta: PT. Gramedia Pustaka Utama.

Levinson, S. C. (1983). Pragmatics. New York: Cambridge Univerity Press. 